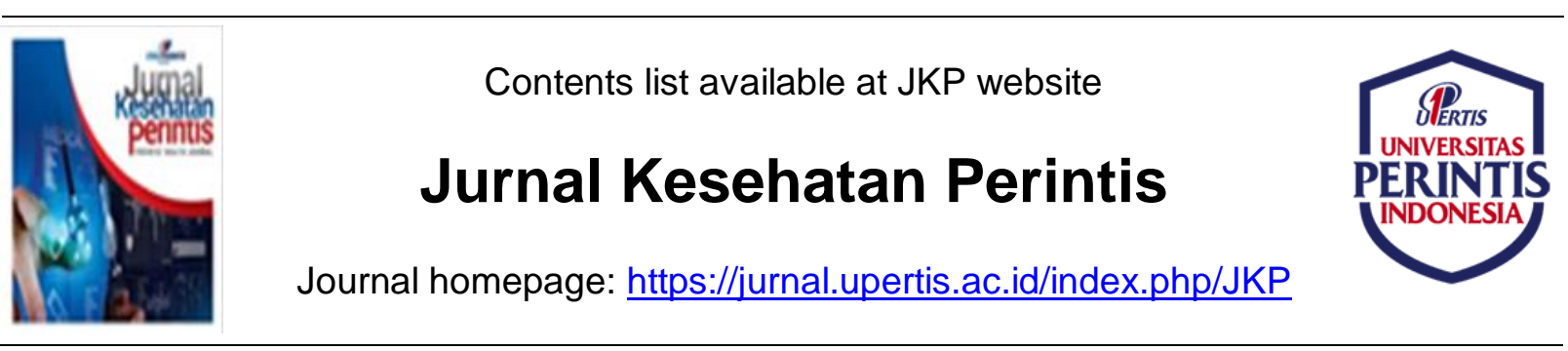

\title{
Aktivitas Antibakteri Kayu Manis (Cinnamomum burmanii) terhadap Pertumbuhan Staphylococcus aureus
}

\author{
Karlina Intan*, Aliansy Diani, Aeni Suci Rizki Nurul \\ Institut Kesehatan Rajawali, Jawa Barat, Indonesia
}

Article Information :

Submission: Nov 8, 2021; Revised:Dec 10, 2021; Accepted:Dec 30, 2021; Available online: Dec 31,2021

${ }^{*}$ Corresponding author : intanbutet@gmail.com

\begin{abstract}
ABSTRAK
Penyakit infeksi yang disebabkan oleh mikroorganisme yaitu bakteri. Bakteri yang sering menyebabkan infeksi kulit adalah bakteri Staphylococcus aureus. Kayu manis (Cinnamomun verum) merupakan tanaman herbal yang sering digunakan sebagai bumbu masakan, namun kayu manis juga memiliki kandungan senyawa kimia seperti flavonoid, alkaloid, saponin, dan triterpenoid yang bersifat antibakteri. Tujuan penelitian ini adalah untuk mengetahui daya hambat ekstrak kayu manis (Cinnamomun verum) terhadap pertumbuhan bakteri Staphylococcus aureus. Jenis penelitian yang digunakan berupa deskriptif eksperimental laboratorium dengan metode pengujian berupa in vitro secara difusi (Kirby-Bauer) menggunakan kertas cakram. Sampel penelitian ialah ekstrak kayu manis (Cinnamomun verum) dengan konsentrasi 30\%, 50\%, 65\%, 70\%, dan 75\% dengan diencerkan DMSO 10\% yang sebelumnya telah dilakukan proses ekstraksi metode maserasi menggunakan pelarut etanol 95\%. Rata-rata hasil pengukuran zona hambat ekstrak kayu manis (Cinnamomun verum) pada konsentrasi 30\%, 50\%, 65\%, 70\%, dan 75\% masing-masing sebesar 3,7 mm, $4,8 \mathrm{~mm}, 5,7 \mathrm{~mm}, 9,7 \mathrm{~mm}$, dan $12,7 \mathrm{~mm}$. Hasil zona hambat pada konsentrasi $30 \%, 50 \%$ dan $65 \%$ dikategorikan lemah (resistent), konsentrasi 70\% dikategorikan sedang (intermediate), dan konsentrasi $75 \%$ dikategorikan kuat (susceptible). Sehingga dari hasil penelitian ini dapat disimpulkan bahwa konsentrasi ekstrak kayu manis (Cinnamomun verum) yang paling efektif dalam menghambat bakteri Staphylococcus aureus adalah $75 \%$ dengan rata-rata zona hambat sebesar $12,7 \mathrm{~mm}$.
\end{abstract}

Kata kunci: staphylococcus aureus, cinnamomun verum, difusi cakram (kirby-bauer)

\section{ABSTRACT}

Infectious diseases caused by microorganisms, namely bacteria. The bacteria that often causes skin infections is Staphylococcus aureus. Cinnamon (Cinnamomun verum) is an herbal plant that is often used as a cooking spice, but cinnamon also contains chemical compounds such as flavonoids, alkaloids, saponins, and triterpenoids which are antibacterial. The purpose of this study was to determine the inhibitory power of cinnamon extract (Cinnamomun verum) against the growth of Staphylococcus aureus bacteria. The type of research used is descriptive experimental laboratory with the test method in the form of in vitro diffusion (Kirby-Bauer) using paper discs. The research sample was cinnamon extract (Cinnamomun verum) with concentrations of $30 \%, 50 \%, 65 \%, 70 \%$, and $75 \%$ with 
$10 \%$ DMSO diluted which had previously been extracted using maceration method using 95\% ethanol as solvent. The average results of the inhibition zone measurements of cinnamon extract (Cinnamomun verum) at concentrations of $30 \%, 50 \%, 65 \%, 70 \%$, and $75 \%$ were $3.7 \mathrm{~mm}, 4.8 \mathrm{~mm}, 5.7 \mathrm{~mm}$, respectively. $9.7 \mathrm{~mm}$, and $12.7 \mathrm{~mm}$. The results of the inhibition zone at concentrations of $30 \%, 50 \%$ and $65 \%$ were categorized as weak (resistant), $70 \%$ concentration was categorized as moderate (intermediate), and $75 \%$ concentration was categorized as strong (susceptible). So from the results of this study it can be concluded that the most effective concentration of cinnamon extract (Cinnamomun verum) in inhibiting Staphylococcus aureus bacteria is $75 \%$ with an average inhibition zone of $12.7 \mathrm{~mm}$.

Keywords: staphylococcus aureus, cinnamomun verum, disc diffusion (kirby-bauer)

\section{PENDAHULUAN}

Luka adalah suatu kondisi atau kerusakan integritas jaringan tubuh. Luka dapat ditimbulkan dari berbagai macam hal seperti tusukan, goresan, luka bakar, bahkan infeksi. (Ariami et al., 2017) Penyebab infeksi nosokomial yang sudah menyebar luas salah satunya adalah bakteri Methicillin Resistant Staphylococcus aureus (MRSA). MRSA ialah bagian strain dari S.aureus yang resisten terhadap antimikroba semua turunan penicillin dan methicillin serta antimikroba spectrum luas B-lactamase. Penanganan infeksi adalah menggunakan pemberian antibiotik, tetapi pemberian antibiotik sering menimbulkan masalah resisten antibiotik pada bidang kesehatan. Cinnamomum verum) terhadap pertumbuhan Methycillin Resistant Staphylococcus aureus (MRSA). (Fikri, 2018)

Penggunaan tumbuhan menjadi obat tradisional dianggap relatif efektif serta aman pada penangan luka, sebab jarang mengakibatkan pengaruh efek samping dan harganya cukup murah. Obat tradisional bisa didapatkan dari biji, buah-buahan, daun, kulit tumbuhan, batang tumbuhan, bunga, maupun akar suatu tumbuhan yang mengandung zat kimia yang mempunyai pengaruh pada pengobatan penyakit. Salah satunya adalah kayu manis, komponen zatzat kimia terbesar pada kayu manis yaitu alkohol sinamat, kumarin, asam sinamat, sinamaldehid, antosinin dan minyak atsiri dengan kandungan gula, protein, lemak sederhana, pektin dan lainnya. Kulit batang kayu manis yang sudah dilakukan ekstrak mengandung senyawa antioksidan utama berupa polifenol (tanin, flavonoid) adapun minyak atsiri golongan fenol. Menyatakan bahwa cinnamon mempunyai kemampuan antimikroba, antifungi, antivirus, antioksidan, antitumor, penurun tekanan darah, kolesterol serta mempunyai senyawa rendah lemak. Senyawa eugenol dan sinamaldehid memiliki potensi sebagai antibakteri. Kayu manis sendiri memiliki beragam jenis, yaitu Cinnamomun burmani, Cinnamomum verum, Cinnamomum loureiroidan Cinnamomum aromaticum. Untuk mendapatkan khasiat kayu manis, maka sebelum digunakan akan dilakukan proses ektraksi. Ekstraksi ialah kegiatan penarikan kandungan kimia yang dapat larut sehingga terpisah dari bahan yang tidak dapat larut dengan pelarut cair. Maserasi merupakan proses pengekstrakkan simplisia dengan menggunakan pelarut dengan cara beberapa kali pengocokan atau pengadukan pada tempratur ruangan (kamar). Cara ini bisa menarik zat-zat yang berkhasiat dan dapat bertahan dalam pemanasan maupun yang tidak dapat bertahan dalam pemanasan.(Reppi et al., 2016)

Berdasarkan berbagai penelitian mengatakan bahwa ektrak kayu manis Cinnamomum burmannii dapat menghambat perkembangan Methycillin Resistant Staphylococcus aureus (MRSA), hal yang sama juga diungkap oleh Aqmarina Betari bahwa Minyak kayu manis (Cinnamomum burmannii) memiliki aktivitas antibakteri dengan nilai diameter hambat $18,773 \pm 0,574 \mathrm{~mm}$ pada konsentrasi $0,1 \%$. Hasil penelitian Repi B Noviano juga mengatakan bahwa ekstrak kulit kayu manis (Cinnamomum burmanni) memiliki efek antibakteri dalam menghambat pertumbuhan Escherichia coli dan 
Streptococcus pyogenes. Pada penelitian Saftratilofa melakukan penelitian uji daya hambat ekstrak kayu manis (Cinnamomum burmannii) terhadap Bakteri Aeromonas hydrophila (Saftratilofa, 2016). Berdasarkan empat jenis kayu manis tersebut, jenis Cinnamomum burmani, Cinnamomun verum adalah dua jenis yang beredar dipasaran Indonesi, tetapi untuk kepentingan penelitian antibiotik hanya jenis kayu manis yaitu Cinnamomun burmani yang paling sering digunakan sementara C. verum jarang digunakan. Pada penelitian ini jenis kayu manis yang digunakan adalah Cinnamomum verum. Tujuan penelitian ini adalah untuk mengetahui daya hambat ekstrak kayu manis (Cinnamomum burmannii) terhadap pertumbuhan bakteri Staphylococcus aureus

\section{METODE PENELITIAN}

Penelitian ini dilakukan pada Laboratorium Bakteriologi Fakultas Kesehatan Institut Kesehatan Rajawali Bandung. Penelitian ini ialah jenis deskriptif eksperimental berupa uji in vitro dengan memakai metode difusi kertas cakram (Kirby bauer) media dibuat sesuai dengan lingkungan optimal yang diperlukan oleh mikroba untuk tumbuh dan berkembang biak. Bahan-bahan yang digunakan pada penelitian ini yaitu Kayu manis (Cinnamomun verum), bakteri Staphylococcus aureus, Nutrient Agar (NA), Agar Muller Hinton (MHA), Nutrient Broth (NB), etanol $95 \%$, larutan $\mathrm{BaCl} 21 \%$, larutan $\mathrm{H} 2 \mathrm{SO} 41 \%$ dan DMSO 10\%. Alatalat yang dipergunakan yaitu: tabung reaksi, jarum ose, cawan petri, pinset, batang $L$, labu erlenmeyer, oven, autoclave, inkubator, pipet ukur, spidol, neraca analitik, api bunsen, dan jangka sorong.
Alat-alat tersebut kemudian disterilkan memakai oven pada suhu $160^{\circ}-180^{\circ} \mathrm{C}$ selama 1 jam. (Ikrom et al., 2014)

Pembuatan ekstrak kayu manis menggunakan kayu manis Cinnamomun verum dilakukan dengan cara ekstraksi metode merasi dengan pelarut etanol 95\% pada suhu ruangan (kamar). Ekstrak kayu manis dilakukan uji fitokimia di Laboratorium Poltekkes Kemenkes Bandung. Hasil ekstrak kemudian dilakukan pengenceran dengan DMSO $10 \%$ dengan dibuat konsentrasi ekstrak 30\%, 50\%, 65\%, $70 \%$, dan $75 \%$. Pengamatan yang dilakukan pada metode difusi parameter yaitu zona hambat yang terbentuk, dengan mengukur diameter zona bening di sekitar cakram menggunakan penggaris dengan mengukur diameter horizontal dan diameter vertikal kemudian hasil yang diperoleh dikurangi diameter cakram $6 \mathrm{~mm}$. Suspensi bakteri Staphylococcus aureus di inokulasikan dengan metode spread plate pada medium Muller Hinton dan diratakan dengan batang $L$, lalu kertas cakram yang telah direndam di ekstrak kayu manis diletakkan pada media Muller Hinton Agar dengan 5 konsentrasi. Selanjutnya di inkubasi selama $24-48$ jam pada suhu 37 ${ }^{0} \mathrm{C}$. Setelah 24-48 jam, diamati serta dihitung zona bening yang terbentuk. (Novaryatiin Susi, 2018)

\section{HASIL PENELITIAN \\ Ekstraksi Kayu Manis (Cinnamomun verum)}

Ekstrak kulit kayu manis dilarutkan dengan pelarut dimethyl sulfoxide (DMSO $10 \%)$ untuk membuat konsentrasi ekstrak $30 \%, 50 \%, 65 \%$, 70\%, dan 75\%. Data hasil pembuatan ekstrak kulit kayu manis pada berbagai konsentrasi terdapat pada tabel 1 .

Kayu manis yang telah dihaluskan

Tabel 1 . Hasil Ekstrak Kayu Manis

\begin{tabular}{cccc}
\hline Konsentrasi Ekstrak & $\begin{array}{c}\text { Volume } \\
\text { Pembuatan }\end{array}$ & $\begin{array}{c}\text { Ekstrak Kayu } \\
\text { Manis yang } \\
\text { Ditimbang }\end{array}$ & $\begin{array}{c}\text { Volume Pelarut } \\
\text { (Dimethyl Sulfoxide } \\
\text { 10\%) }\end{array}$ \\
\hline $30 \%$ & $10 \mathrm{ml}$ & $3 \mathrm{~g}$ & $10 \mathrm{ml}$ \\
$50 \%$ & $10 \mathrm{ml}$ & $5 \mathrm{~g}$ & $10 \mathrm{ml}$ \\
$65 \%$ & $10 \mathrm{ml}$ & $6,5 \mathrm{~g}$ & $10 \mathrm{ml}$ \\
$70 \%$ & $10 \mathrm{ml}$ & $7 \mathrm{~g}$ & $10 \mathrm{ml}$ \\
$75 \%$ & $10 \mathrm{ml}$ & $7,5 \mathrm{~g}$ & $10 \mathrm{ml}$ \\
\hline
\end{tabular}


dengan mesin penghalus, kemudian dilakukan maserasi dengan menggunakan pelarut etanol $96 \%$ selama 4 hari (gambar 1). Ekstrak disaring menggunakan penyaring vakum. Kemudian filtrat hasil maserasi diuapkan dalam rotary evaporator pada suhu $50-60^{\circ} \mathrm{C}$ selama 1 hari untuk mendapatkan ekstrak kental. Ekstrak Kayu manis yang ditimbang dalam pembuatan berbagai konsentrasi ekstrak adalah ekstrak kental yang didapat pada proses ini.

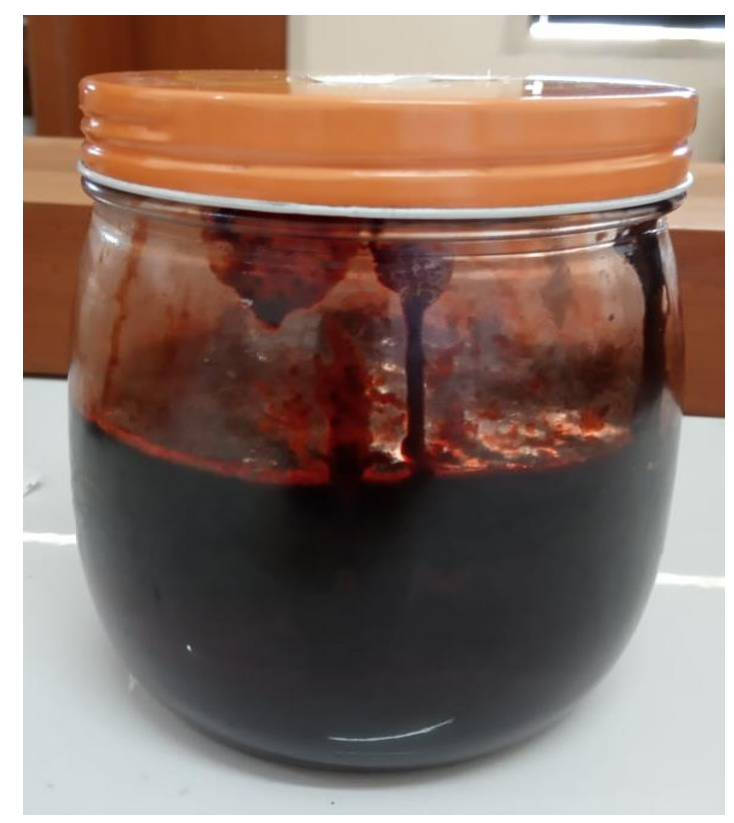

\section{Gambar 1. Hasil Ekstraksi-Maserasi Kayu Manis (Cinnamomun verum) dengan pelarut etanol $96 \%$}

\section{Hasil Dari Uji Fitokimia}

Kulit kayu manis yang sudah di ekstrak kemudian dilakukan uji fitokimia yang bertujuan untuk mengetahui senyawa yang terkandung dalam kayu manis sebagai zat antimikroba. Hasil uji fitokimia senyawa yang teridentifikasi dalam kayu manis adalah Flavonoid, Alkaloid, Saponin, dan triterpenoid (tabel 2). Hasil Uji Fitokimia Ekstrak Kayu Manis (Cinnamomun verum)(gambar 2).

Bakteri Staphylococcus aureus merupakan bakteri yang biasa ditemukan diluka pada kulit. Luka sulit sembuh apabila terdapat bakteri yang hidup padanya. Oleh karena itu perlu zat antibakteri yang diberikan untuk menghambat adanya infeksi bakteri. Metode uji yang digunakan dalam uji efektivitas penghambatan bakteri adalah metode difusi cakram (Kirby Bauer). (Ekawati et al., 2018)

Metode difusi cakram merupakan pengukuran daerah zona bening yang terbentuk di sekitar kertas cakram yang digunakan untuk mengetahui aktivitas antimikroba. Kertas cakram direndam dalam larutan ekstrak kayu manis selama 15 menit dengan tujuan agar ekstrak menyerap secara sempurna kedalam kertas cakram, selanjutnya diletakkan pada media yang telah ditanami oleh bakteri. Pengujian daya hambat bakteri ditandai dengan terbentuknya zona bening pada permukaan media agar. (Fitri Sri Rizki, 2020) Kelebihan dari metode difusi cakram yaitu proses pengujian cepat, biaya relatif murah, mudah dan tidak memerlukan keahlian khusus. Sedangkan kelemahan dari metode ini yaitu sulit untuk diaplikasikan pada mikroorganisme yang perkembangannya lambat dan zona bening yang terbentuk dipengaruhi pada kondisi inkubasi, inokulum serta ketebalan medium.(Handayani et al., 2018; Sarosa et al., 2018).

Data hasil penelitian yang diperoleh dengan memberikan perlakuan langsung pada medium yang telah ditanami oleh bakteri Staphylococcus aureus. Pembuatan suspensi bakteri Staphylococcus aureus distandarisasi dengan larutan Mc Farland 0,5 yang terdiri dari $9,95 \mathrm{~mL}$ larutan $\mathrm{H}_{2} \mathrm{SO}_{4}$ $1 \%$ dan $0,05 \mathrm{ml}$ laruan $\mathrm{BaCl} 1 \%$ yaitu setara dengan kepadatan bakteri $1,5 \times 10^{8}$ CFU/ml.(Sarosa et al., 2018).

Berdasarkan tabel 3 hasil pengamatan daya hambat ekstrak kulit kayu manis (Cinnamomun burmani) terhadap bakteri Staphylococcus aureus setelah diinkubasi selama 48 jam menunjukkan terbentuknya zona bening pada semua konsentrasi. Diameter zona hambat yang terbentuk ukurannya berbeda-beda, kemudian diukur menggunakan penggaris yang dilakukan dengan cara mengukur diameter horizontal dan diameter vertikal lalu hasil yang diperoleh dikurangi diameter cakram $6 \mathrm{~mm}$. Pada ekstrak kulit batang kayu manis dengan konsentrasi $30 \%, 50 \%$, dan $65 \%$ memberikan daya hambat lemah dengan rata-rata dari masing-masing zona hambat sebesar $3,7 \mathrm{~mm}, 4,8 \mathrm{~mm}$ dan $5,7 \mathrm{~mm}$ 
Tabel 2. Hasil Uji Fitokimia

\begin{tabular}{lcl}
\multicolumn{1}{c}{$\begin{array}{c}\text { Senyawa yang } \\
\text { diidentifikasi }\end{array}$} & Interpretasi Hasil & \multicolumn{1}{c}{ Keterangan } \\
\hline Flavonoid & Positif & Terbentuk warna merah \\
Alkaloid & Positif & Terbentuk warna merah \\
Saponin & Positif & Terbentuk busa \\
Tanin & Negatif & Tidak terbentuk warna hitam pekat \\
Triterpenoid & Positif & Terbentuk cincin kecoklatan \\
Steroid & Negatif & Tidak terbentuk perubahan warna \\
\hline
\end{tabular}
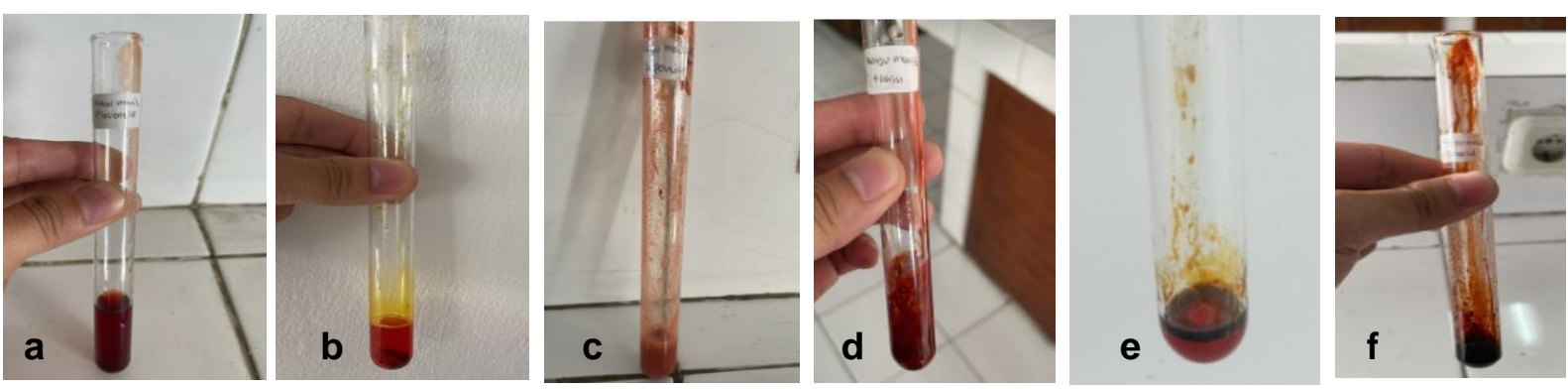

Gambar. 2 . Hasil Uji Fitokimia Ekstrak Kayu Manis (Cinnamomun verum) senyawa (a) Flavonoid, (b) Alkaloid, (c) Saponin, (d) Tanin, (e) Triterpenoid, (f) Steroid

termasuk kategori lemah, konsentrasi $70 \%$ menghasilkan rerata daya hambat sebesar 9,7 $\mathrm{mm}$ termasuk kategori sedang dan konsentrasi $75 \%$ menghasilkan rerata daya hambat kuat dengan zona hambat sebesar $12,7 \mathrm{~mm}$. Kategori diameter zona hambat ini disesuaikan berdasarkan Susanto tahun 2012. (Nurnasari Wijayanti, 2019) Diameter zona hambat menjadi tolak ukur terhadap kekuatan dari senyawa yang terkandung dalam ekstrak kayu manis dan menandakan bahwa semakin besar daya hambat yang terbentuk oleh mikroba maka semakin kuat pula senyawa aktif yang dapat menghambat pertumbuhan bakteri. (Amrie et al., 2015)

Pada tabel 3 hasil dari zona bening masing-masing konsentrasi memiliki diameter yang berbeda. Besarnya perbedaan diameter hambat ini dapat disebabkan oleh beberapa faktor antara lain konsentrasi ekstrak yang diberikan, kecepatan difusi bahan antimikroba pada media agar, jumlah bakteri yang di inokulasikan, temperatur suhu inkubasi, kepekaan terhadap pertumbuhan bakteri dan reaksi antara bahan aktif dengan medium. (Dewi et al., 2019).

Senyawa metabolit sekunder yang terkandung dalam ekstrak kayu manis dapat mempengaruhi daya hambat bakteri Staphylococccus aureus yaitu senyawa flavonoid, alkaloid, saponin, dan triterpenoid. Senyawa falvonoid diketahui dapat merusak membram sel bakteri dengan cara menghambat sintesis protein. Mekanisme kerja alkaloid yaitu merusak sel bakteri dengan cara menghambat

Tabel 3. Hasil Uji Daya Hambat

\begin{tabular}{|c|c|c|c|c|c|}
\hline \multirow[b]{2}{*}{ Konsentrasi } & \multicolumn{3}{|c|}{ Ulangan } & \multirow{2}{*}{$\begin{array}{c}\text { Rata-rata } \\
\text { Diameter } \\
(\mathrm{mm})\end{array}$} & \multirow[b]{2}{*}{ Kategori } \\
\hline & 1 & 2 & 3 & & \\
\hline $30 \%$ & 3,5 & 3 & 4,5 & 3,7 & lemah \\
\hline $50 \%$ & 5 & 5,5 & 4 & 4,8 & lemah \\
\hline $65 \%$ & 5,5 & 5,5 & 6 & 5,7 & lemah \\
\hline $70 \%$ & 7,5 & 8,5 & 13 & 9,7 & sedang \\
\hline $75 \%$ & 16 & 12,5 & 8 & 12,7 & kuat \\
\hline
\end{tabular}



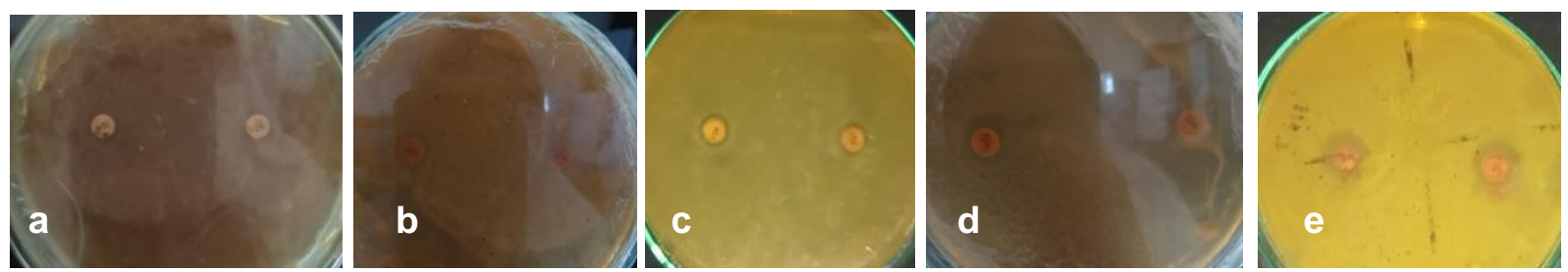

Gambar 3. Hasil Zona Hambat bakteri Staphylococcus aureus

Konsentrasi (a) $30 \%$, (b) $50 \%$, (c) $65 \%$, (d) $70 \%$, (e)75\%

pembentukan sel sehingga menyebabkan kematian bakteri. Senyawa saponin diketahui memiliki mekanisme antibakteri dengan mengganggu permeabilitas membran sel bakteri. (Ernawati \& Sari, 2015) Senyawa terpenoid juga memiliki mekanisme kerja sebagai antimikroba dengan cara merusak dan mengurangi permeabilitas dinding sel bakteri sehingga sel bakteri kekurangan nutrisi dan perkembangan bakteri menjadi terhambat bahkan mati. (Wulansari et al., 2020)

\section{KESIMPULAN}

Konsentrasi kayu manis yang paling efektif untuk menghambat pertumbuhan Staphylococccus aureus adalah konsentrasi $75 \%$ dengan rerata diameter zona bening sebesar $12,7 \mathrm{~mm}$. Secara berturut-turut potensi yang terbaik adalah ekstrak dengan konsentrasi $65 \%, 70 \%$, dan paling baik adalah $75 \%$.

\section{UCAPAN TERIMA KASIH}

Kementerian Riset dan Teknologi Pendidikan Tinggi yang telah memberikan pendanaan pada penelitian ini dengan kontrak Nomor : 065/SP2H/DRPM/2021, laboratorium Politeknik Kesehatan Kota Bandung dan laboratorium Institut Kesehatan Rajawali yang telah memfasilitasi penelitian ini.

\section{REFERENSI}

Amrie, A. G. al, Ivan, Anam, S., \& Ramadhanil. (2015). Uji Efektifitas Ekstrak Daun dan Akar Harrisonia perforata Merr. terhadap Pertumbuhan Bakteri Vibrio cholerae. Jurnal of Natural Science, 3(3), 331-340. http://jurnal.untad.ac.id/jurnal/index.php /ejurnalfmipa/article/view/3343/2382

Ariami, P., Danuyanti, I., \& Anggraeni, B. R. (2017). Efektifitas Teh Kulit Buah Manggis (Garcinia mangostana L)
Sebagai Antimikroba Terhadap Ppertumbuhan Bakteri MethicillinResistant Staphylococcus aureus (MRSA). Teknologi Laboratorium, 3(6), 3-8.

Dewi, S., Asseggaf, S. N., Natalia, D., \& Mahyarudin, M. (2019). Efek Ekstrak Etanol Daun Kesum (Polygonum minus Huds.) sebagai Antifungi terhadap Trichophyton rubrum. Jurnal Kesehatan Andalas, 8(2), 198. https://doi.org/10.25077/jka.v8i2.992

Ekawati, E. R., Husnul Y., S. N., \& Herawati, D. (2018). Identifikasi Kuman Pada Pus Dari Luka Infeksi Kulit. Jurnal SainHealth, 2(1), 31. https://doi.org/10.51804/jsh.v2i1.174.31 $-35$

Ernawati, \& Sari, K. (2015). Kandungan Senyawa Kimia dan Aktivitas Antibakteri Ekstrak Kulit Buah Alpukat (Persea americana P.Mill) Terhadap Bakteri Vibrio alginolyticus. Jurnal Kajian Veteriner, 3(3), 203-211.

Fikri, M. (2018). Uji Daya Hambat Ekstrak Etanol Kayu Manis (Cinnamomum burmanni) Terhadap Pertumbuhan Methycillin Resistant Staphylococcus aureus (MRSA).

Fitri Sri Rizki*, A. F. (2020). Uji Daya Hambat Antibakteri Salep Ekstrak Etanol Daun Pandan Hutan (Freycinetia sessiliflora Rizki.) Terhadap Pertumbuhan Bakteri Staphylococcus epidermidis. Jurnal Ilmiah Ibnu Sina, 5(1), 1-9.

Handayani, R., Qamariah, N., \& Mardova, S. A. (2018). Uji Daya Hambat Ekstrak Etanol Batang Saluang Belum terhadap Bakteri Escherichia coli. Borneo Journal of Pharmacy, 1(1), 1618.

https://doi.org/10.33084/bjop.v1i1.237

Ikrom, Asih, D., Wira, R., Perkasa, B., Tiara, R., \& Wasito. (2014). Studi In 
Vitro Ekstrak Etanol Daun Kamboja ( Plumeria alba ) sebagai Anti Aeromonas hydrophila. Jurnal Sain Veteriner, 32(1), 105-116.

Nurnasari, E., \& Wijayanti, K. S. (2019). Aktivitas Antibakteri Minyak Atsiri Daun Tembakau terhadap Pertumbuhan Bakteri Escherichia coli dan Staphylococcus aureus. Jurnal Kefarmasian Indonesia, 9(1), 48-56. https://doi.org/10.22435/jki.v9i1.1219

Reppi, N. B., Mambo, C., \& Wuisan, J. (2016). Uji efek antibakteri ekstrak kulit kayu manis (Cinnamomum burmannii) terhadap Escherichia coli dan Streptococcus pyogenes. Jurnal EBiomedik, 4(1). https://doi.org/10.35790/ebm.4.1.2016. 12204

Saftratilofa. (2016). Uji Daya Hambat Ekstrak Daun Kayu Manis (Cinnamomum burmanii) Terhadap Bakteri Aeromonas hydrophila. Jurnal IImiah Universitas Batang Hari, 16(1), 98-103.
Sarosa, A. H., P, H. T., Santoso, B. I., Nurhadianty, V., \& Cahyani, C. (2018). Pengaruh Penambahan Minyak Nilam Sebagai Bahan Aditif Pada Sabun Cair Dalam Upaya Meningkatkan Daya Antibakteri Terhadap Staphylococcus aureus. Indonesian Journal of Essential Oil, 3(1), 1-8. https://ijeo.ub.ac.id

Susi Novaryatiin1, Rezqi Handayani1, R. C. (2018). Uji Daya Hambat Ekstrak Etanol Umbi Hati Tanah (Angiotepris SP.) Terhadap Bakteri Staphylococcus aureus. Jurnal Surya Medika, 3(2), 2331. https://doi.org/10.33084/jsm.v3i2.93

Wulansari, E. D., Lestari, D., \& Khoirunissa, M. A. (2020). Kandungan Terpenoid Dalam Daun Ara (Ficus carica L.) Sebagai Agen Antibakteri Terhadap Bakteri Methicillin-Resistant Staphylococcus aureus. Pharmacon, 9(2), 219-225. https://doi.org/10.35799/pha.9.2020.29 27 